\title{
Strategic Management of Nature-Based Tourism in ljen Crater in the Context of Sustainable Tourism Development
}

\author{
Sandra Dhesitta Putri ${ }^{1^{*}}$, Soemarno ${ }^{2}$, Luchman Hakim ${ }^{3}$ \\ ${ }^{1}$ Master Program of Environmental Sciences, Graduate Program, University of Brawijaya, Malang, Indonesia \\ ${ }^{2}$ Faculty of Agriculture, University of Brawijaya, Malang, Indonesia \\ ${ }^{3}$ Department of Biology, Faculty of Mathematics and Natural Sciences, University of Brawijaya, Malang, Indonesia
}

\begin{abstract}
The aim of the study is to define the strategic management of nature based tourism in ljen crater, East Java. From the perspectives of accessibility, problems facing by accessibility are related to the travel distance and forest road quality. Ijen craters have three important aspect in competitiveness tourism aspect, namely something to see (mountain landscape), something to do (trekking, hiking, bird watching), and something to buy (meals). The future development of such attraction should be meets ecotourism principles. This study found that improving tourism facility and infrastructure were important aspects. The development and improvement of tourism facility and infrastructure, however, should be incorporates ecotourism principles. In such a case, the conservation, local people and community development becomes crucial issue. Involvement of stakeholder and local community in facility and infrastructure will increase the quality and sustainability of infrastructure and tourism facility.
\end{abstract}

Keywords: ecotourism strategy, tourism management.

\section{INTRODUCTION}

Recently the development of strategic planning and implementation of tourism has been considered important. It is especially important in many cases where tourist visitation to natural ecosystems and environment grows significantly. Are with abundance resources, such as forest, waterfall, rivers, crater, grasslands, caldera, lake have a significant role in tourism destination development. Scholars point out that numerous natural ecosystems have been suffered from mass tourism which is to decrease biodiversity level. Tourism in natural environment therefore needs to be managed properly, especially in order to protect biodiversity and enhance the sustainable uses of natural resources [1-3].

Recent issues in sustainable tourism argue that comprehensive destination management is important. Destination management should be embraced cultural integrity, ecological process, biodiversity and other related systems which are contribute to sustainable living systems in harmony. Many destination however lack of the ability to maintain sustainable issues and therefore vulnerable to degradations. Scholars point out that many fragile ecosystems such as mountain, forest and beach are suffered from

\footnotetext{
* Correspondence address:

Sandra Dhesitta Putri

Email : sandra30588@yahoo.com

Address : Graduate Program, University of Brawijaya, Mayjen Haryono No. 169, Malang 65145
}

tourism activity. One of the crucial threats to the sustainability of the mountain ecosystem is related to the increasing number of tourism beyond carrying capacity. Increasing number of tourism often responded by rapid and massive physical development of tourism infrastructure. There are intensive land uses changes and wildlife habitat clearing to provides adequate spaces for tourism infrastructure development. The infrastructure development often ignored ecotourism principles which are important to ensure ecosystem sustainability $[2,4]$.

In many nature-based tourism destinations, practicing sustainable tourism development tourism is one of the principal problems. There are lacks of basic tourism philosophy which are important to drive tourism into sustainable practices. Infrastructure has been build without considering local characteristics and local wisdoms. Many nature-based tourism destinations are lack of the integrative tourism strategic planning which is suitable for local environments and meets the ecotourism principles. These aspects are leading to the poor of destination competitiveness [4].

Ijen crater is one of the important tourism destinations in East Java. The geological attraction of ljen craters is actives crates and sulfur lakes with blue-green waters. The mountainous landscapes were beautiful. Tourism grows significantly. In 20014, about 6.722 domestic tourism recorded in ljen Craters while international tourism was recorded about 28.668 
[5]. Effort to increase tourism performance in Ijen crater has been implemented by local government and related agencies, i.e Banyuwangi dan Bondowoso Regency. As far, the comprehensive evaluation of destination sustainability was absent. The objective of the research is to evaluate the recent condition of tourism implementation and build the strategic management of nature-based tourism development in ljen crater.

\section{MATERIALS AND METHODS}

\section{Study Area}

Ijen Crater located at the border of Banyuwangi and Bondowoso Regency (Fig.1). Ijen Crater is one of the famous mountain based tourism attraction in East Java. Administratively, Ijen Crater belong to the protected area system, namely Ijen Strict Nature Reserve. Ijen Crater is the recreation area with 92 hectares. The area divided into two area management, namely intensive uses zone (23.85 ha) and protection area (62.58 ha). In the intensive uses zone, there are official buildings, tourism infrastructure, parking area, shelter, toilet, and restaurant and camping ground area [6]. The natural attraction of ljen craters is active volcanic and sulfur lake with green colors. The Biodiversity of Ijen Crater was considered high. Forest fire and vandalism is one of the important threat to Ijen Craters. Recently, however, scholar identify that invasion of exotic plant species become the important threats to the ljen crater ecosystems [7].

\section{Data Collection and Analysis}

Research consists of secondary data collection, questionnaires and field observation. Secondary data collection was done through official visitation in office of Tourism of Banyuwangi Regency, office of tourism in Bondowoso Regency, Nature conservation Agency (BKSDA) and regional office of National Statistic Office in Banyuwangi. Focus of the research was data and information regarding regional planning policy and implementation, regency policy regarding tourism development, and tourism statistics.

Four aspect namely tourism accessibility, attraction, facility and the contribution of stakeholder in tourism development was evaluated descriptively. The assessment was implemented based on direct observation and interviews with respondents in the field. Focus of the assessments the basic feature of tourism accessibility, attraction, facility and the contribution of stakeholder. Mainly, it is encompasses internal factor of the destination, i.e. strengths and weaknesses.

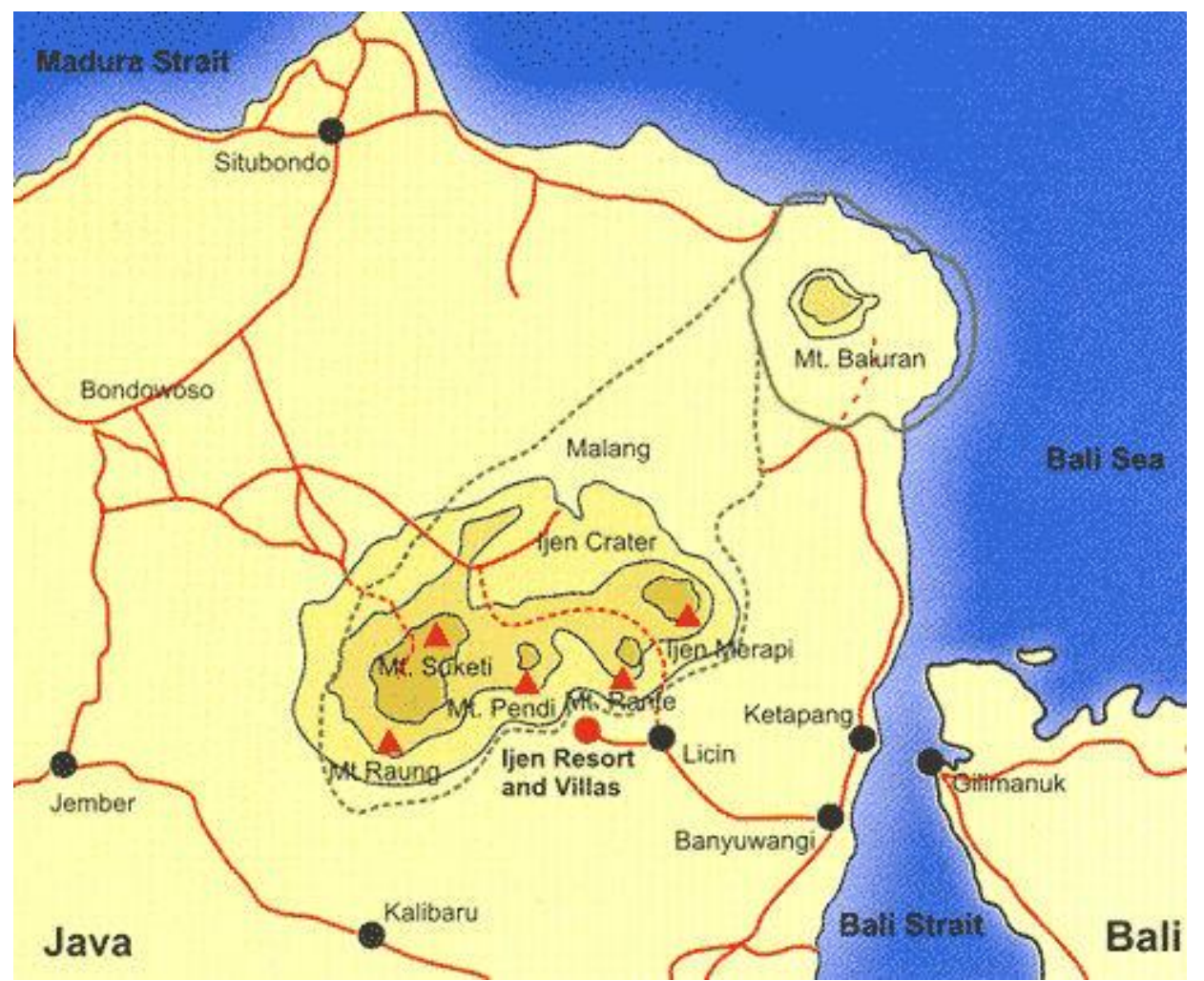

Figure 1. Ijen Crater tourism area is part of important biodiversity area in the eastern part of East Java Province [8] 
In this study, management performance of tourism in ljen crater was implemented to identify the scenario for sustainable tourism development and biodiversity conservation. Tree aspects, namely physical, economical and social aspects were evaluated using questionnaire instruments. The questionnaire was distributed to the both local and domestic tourist in October 2014. Respondents sampling was done through accidental sampling. Totally, the questionnaire was distributes to the 60 tourist. Each important aspect of such factors was assessed using Sturgest interval criteria using calculation formula of Nazir [9]:

$$
\begin{array}{ll}
K=1+3.3 \log n & K=1+3.3(1,079) \\
K=1+3.3(\log 12) & K=4.56 \approx 4
\end{array}
$$

From these calculation, intervals of respondens's answer related to physical, economical and social aspecs were classified as poor (interval value 12-21), moderates (interval value 21-30), Good (interval value 30-39), and Excellence (interval value 39-48).

In order to describe the strategy of Ijen crater, the Internal Strategic Factors Analysis and External Strategic Factors Analysis was implemented. The strength, weaknesses, opportunities and threats of tourism implementation and development in ljen was assessed comprehensively.

\section{RESULTS AND DISCUSSION \\ Acessibility}

Access to ljen carter can be reach from Banyuwangi and Bondowoso. Tourist from Surabaya (the capital city of East Java) and its surrounding area can reach ljen Crater from Bondowoso. Tourist from Bali can reach Ijen crater from Banyuwangi. There are road to connect Bondowoso and Banyuwangi where Ijen crater can reach easily.

Problems facing by accessibility are related to the travel distance and forest road quality. In some place, the condition of road was poor and need to be improved. Safety concern was poor and this is can be crucial issues in tourism destination competitiveness. Access from Bondowoso relatively flat, but there are many road holes and gravels. Access from Banyuwangi is relatively hard because physically tourist vehicle is passing the hard roads in undulating humid tropical forest. In some point, there are steepest slopes.

Attention to the forest road quality was important due to the number of both international and domestic tourism to Ijen Craters grows significantly (Table 1). In Indonesia, poor accessibility was common in tourism destination. Effort to increase accessibility therefore important. Tourist trend to natural environments recently recognized as a new lifestyle for numerous developed countries, especially among European and American countries. In the future, it is predicted that tourism grows in natural environment in East Asia and Oceania grows significantly [10]. In such a case, however, infrastructure was important to facilitate tourist moving.

Table 1. Tourist profile in ljen Crater from 2011 to 2014

\begin{tabular}{cccc}
\hline No. & Years & International tourist & Domestic tourist \\
\hline 1. & 2014 & 28,668 & 6,722 \\
2. & 2013 & 21,579 & 4,315 \\
3. & 2012 & 1,412 & 2,218 \\
4. & 2011 & 7,643 & 8,785 \\
\hline
\end{tabular}

Source : Office of Tourism and Culture, Banyuwangi [5]

The commitment of local government in Banyuwangi Regency to improve road quality was good. It is showed by the project of forest road improvement from Banyuwangi to Ijen craters. These improvements are also important to increase the quality of the international cycling tournament called Tour de Ijen. Scholar point out that response of local government to build systems which was able to allow tourism destination accessible is important. It is become the basic strategy among government and society to increase number of tourist [3]. Recent data about tourism in Banyuwangi show significant increase in tourism, including visitation to ljen which are recoded from Banyuwangi.

\section{Tourism attractions}

Tourism attraction in ljen craters can be identified into tree aspect, namely something to see, and something to do, something to buy (Table 2). This research found such aspect in Ijen crater, but the future development of such attraction should be meets ecotourism principles. The impelementation of ecotourism principles is improtant in order to ensure the protection of natural and cultural resources.

\section{Tourism facility}

Tourism facility is important aspect in visitor satisfaction [11]. Tourism vafility has psycologiacl consequences at a visitors satisfaction aspect. The availability and quality of tourism facility will 
affect tourist satisfaction to particular destinations. In Ijen Craters, however, these facility needs to be impproved. This resources found and draws several important aspect of facility improvement as shown in Table 3.

Table 2. Management strategic to improve tourism attraction in Ijen Crater

\begin{tabular}{|c|c|c|}
\hline Aspects & Object and activity & Development concept to meet ecotourism \\
\hline \multirow[t]{3}{*}{ something to see } & Ijen crater & $\begin{array}{l}\text { - Enhancing conservation effort of crater and its surrounding area by } \\
\text { monitoring human activities which are potentially disturb crater } \\
\text { ecosystem }\end{array}$ \\
\hline & Mountainous landscapes & $\begin{array}{l}\text { - Monitoring human activities which are potentially disturb mountain } \\
\text { ecosystem, including illegal logging, vandalism, exotic plant species } \\
\text { invasion, and forest fire. In ljen forest, fire is one of the crucial agent } \\
\text { of mountain vegetation disturbance. }\end{array}$ \\
\hline & Flora and Fauna & $\begin{array}{l}\text { - Increasing integrated conservation effort, compiling biodiversity data } \\
\text { base, and designing proper integrative conservation planning } \\
\text { - Increasing protection and law enforcement }\end{array}$ \\
\hline \multirow[t]{3}{*}{ something to do } & Trekking & $\begin{array}{l}\text { - Increasing trekking corridors, establishing fence in some dangerous } \\
\text { point, re-vegetation activity in some point to minimize and } \\
\text { countermeasure land slide along tourist corridors. }\end{array}$ \\
\hline & Cultural and social events & $\begin{array}{l}\text { - Exploring potential activity which are able to satisfy tourism } \\
\text { - Increasing tourist participation in the community development in an } \\
\text { area surrounding ljen Crater, } \\
\text { - Promoting tourism involvement in peasant activity i.e. coffee harvest } \\
\text { festival. }\end{array}$ \\
\hline & Out bond & $\begin{array}{l}\text { - Development sustainable outbound program, including sustainable } \\
\text { equipment for out bond and camping ground }\end{array}$ \\
\hline \multirow[t]{3}{*}{ Something to buy } & Accommodations & $\begin{array}{l}\text { - Providing sustainable eco-lodge following ecotourism standard and } \\
\text { environmental safety }\end{array}$ \\
\hline & Souvenir & $\begin{array}{l}\text { - Educating local people to produce local souvenir using local material } \\
\text { and reduce-cycling process }\end{array}$ \\
\hline & Food and culinary & $\begin{array}{l}\text { - Promoting local culinary and education local people to establish } \\
\text { restaurant according to proper standard }\end{array}$ \\
\hline
\end{tabular}

Table 3. Strategy for tourism facility management

\begin{tabular}{|c|c|}
\hline Facility & Management concept \\
\hline \multicolumn{2}{|l|}{ Main facility } \\
\hline \multirow[t]{3}{*}{ Accomodation } & - Increasing number and quality of homestay \\
\hline & - Improvement of accomodation facility \\
\hline & - Management and maintanace of accomodation facility \\
\hline Camping ground & $\begin{array}{l}\text { - Managging camping ground in susutainable manner, including visitor number management } \\
\text { - Incresing outbond facility, including flying fox, tree top walk, bridge trees, painball }\end{array}$ \\
\hline Rest building (Gazebo) & - Incresing number of rest house (Gazebo) \\
\hline facility & $\begin{array}{l}\text { - Improving park arrangement and landscaping using indigenous plants. Reduce artificial } \\
\text { ornaments, including exotic plant species }\end{array}$ \\
\hline $\begin{array}{l}\text { Information mark and } \\
\text { direction }\end{array}$ & $\begin{array}{l}\text { Number of information mark and direction should be improved to allow tourist found the road } \\
\text { to access main destination safely }\end{array}$ \\
\hline \multirow[t]{2}{*}{ Corridors network } & - Tourism corridors improvement from Paltuding to craters \\
\hline & - Phisical building to countermeasure land slide in some points \\
\hline Fresh waters availability & - Establishing fresh water instalation properly, especialy to support tourism needs \\
\hline Electricity & - Establishing electricity in Paltuding \\
\hline \multicolumn{2}{|l|}{ Secondary facility } \\
\hline Information centre & - Maintannace of information facility \\
\hline \multirow[t]{2}{*}{ Parking area } & - Enlargement of parking area without clearing vegetation \\
\hline & - Site management for parking area. Management should be able to minimize erosion risk \\
\hline \multirow[t]{2}{*}{ Toilet } & - Increasing number and capacity of toilet in Paltuding post \\
\hline & - Increasing cleaness of toilet. Intaling water system and drainage to ensure environmental health \\
\hline Roads & $\begin{array}{l}\text { - Increasing safety, especialy along treeking corridors from Paltuding to crater } \\
\text { - Increasing number of forest ranger to control tourist behaviour }\end{array}$ \\
\hline Waste box & - Increasing number and maintaining waste baskets and waste management in ljen crater \\
\hline Praying room & - Increasing quality of paying rooms in Paltuding Post \\
\hline
\end{tabular}




\section{Stakeholder analisys}

Stakeholder plays an important role in tourism planning, iplementation and monitoring. Tourism stakeholders has been reported contributes to tourism development. According Bolnick [12], the strategic and interesting role of tourism in local economic developments should be considered as one of the reasons to integrate society and tourism in development issues. From numerous aspect of stakeholder contribution in tourism development in ljen crater, the contribution of stakeholder can be focused to the two crucial aspect, namelly funding support and collaborations (Table 4). These two aspect were identified important to enhance the competiti- veness of ljen cater as nature-based tourism destination in East Java.

\section{The performance of Ijen Crater management}

The performance of tourism development was summarized in Table 5. From the perspective of physical, economic and social aspects, the evaluation grade were ranging from moderates to good, except for respecting local culture aspect. In order to increase destination competitiveness and tourist satisfaction, some improvements need to be implemented. It is especially crucial in the perspective of destination marketing and competitiveness [11].

Table 4. Stakeholder management in the development of ijen craters as a competitive tourism destination

\begin{tabular}{|c|c|}
\hline Aspects & Notes \\
\hline Funding & $\begin{array}{l}\text { - Transparency in funding policy, equal sharing benefits, increasing involvement of CSR support to ensure the } \\
\text { sustainability of community development and completing tourism facility }\end{array}$ \\
\hline Collat & $\begin{array}{l}\text { - Increasing collaboration between stakeholders. The role government to facilitate collaboration as } \\
\text { important. }\end{array}$ \\
\hline $\begin{array}{l}\text { Tourism } \\
\text { program }\end{array}$ & $\begin{array}{l}\text { - Increasing tourism programs which are meet to ecotourism principles, including education and involving } \\
\text { community development }\end{array}$ \\
\hline
\end{tabular}

Table 5. The performance of tourism in ljen crater based on economic, social and cultural aspect

\begin{tabular}{|c|c|c|c|c|c|c|}
\hline \multirow{2}{*}{ Variables } & \multicolumn{4}{|c|}{ Grade value } & \multirow{2}{*}{$\begin{array}{c}\text { Result of } \\
\text { asessment }\end{array}$} & \multirow{2}{*}{ Notes } \\
\hline & (1) & (2) & (3) & (4) & & \\
\hline \multicolumn{7}{|l|}{ Phisical aspects } \\
\hline $\begin{array}{l}\text { Considering carring } \\
\text { capacity activity } \\
\text { planning and sustainable } \\
\text { growth }\end{array}$ & & & $\mathbf{v}$ & & 3 & $\begin{array}{l}\text { Development has meet sustainability principles, but the } \\
\text { usage was inefficient. In high season of tourist visitation, } \\
\text { however, visitor number and its activity should be } \\
\text { controled. }\end{array}$ \\
\hline $\begin{array}{l}\text { Protecting biodiversity } \\
\text { and environments }\end{array}$ & & $\mathbf{v}$ & & & 2 & $\begin{array}{l}\text { The comprehensive planning of biodiversity and its } \\
\text { implementation needs to be improved }\end{array}$ \\
\hline $\begin{array}{l}\text { Minimum impact to } \\
\text { environment }\end{array}$ & & & & $\sqrt{ }$ & & $\begin{array}{l}\text { The environmental protection has been implemented, but } \\
\text { the practices should be improved }\end{array}$ \\
\hline $\begin{array}{l}\text { Meets the cultural and } \\
\text { physical value of } \\
\text { environment }\end{array}$ & & & $\sqrt{ }$ & & 3 & $\begin{array}{l}\text { Local values has accommodate in some building } \\
\text { architecture; but there are need integration strategy with } \\
\text { other facility }\end{array}$ \\
\hline $\begin{array}{l}\text { Reduce water } \\
\text { consumption }\end{array}$ & & $\boldsymbol{V}$ & & & 2 & $\begin{array}{l}\text { Fresh water conservation and management should be } \\
\text { improved }\end{array}$ \\
\hline Waste management & & $\mathbf{v}$ & & & 2 & $\begin{array}{l}\text { Waste management should be improved to minimize } \\
\text { tourism impact to enviroment }\end{array}$ \\
\hline \multicolumn{7}{|l|}{ Economic } \\
\hline $\begin{array}{l}\text { Research program in the } \\
\text { contribution of tourism } \\
\text { to local economic }\end{array}$ & & $\sqrt{ }$ & & & 2 & $\begin{array}{l}\text { Lack of research program in economic impact of tourism } \\
\text { contributes to the less appreciation of community to active } \\
\text { participation in tourism sectors }\end{array}$ \\
\hline $\begin{array}{l}\text { Tourism contributes to } \\
\text { the local economic }\end{array}$ & & & $\mathbf{v}$ & & 3 & $\begin{array}{l}\text { Tourism has contributes to some local people, but there } \\
\text { should be enlage to ther community }\end{array}$ \\
\hline $\begin{array}{l}\text { Funding allocation for } \\
\text { forest conservation }\end{array}$ & & $\mathbf{v}$ & & & 2 & $\begin{array}{l}\text { As far, funding support for biodiversity conservation was } \\
\text { less. Another sources of funding shoild be explored. }\end{array}$ \\
\hline \multicolumn{7}{|l|}{ Social } \\
\hline $\begin{array}{l}\text { Cooperation with local } \\
\text { people }\end{array}$ & & $\mathbf{v}$ & & & 2 & $\begin{array}{l}\text { The cooperation with stakeholder is important but in some } \\
\text { case it was neglected }\end{array}$ \\
\hline $\begin{array}{l}\text { Tourism contributes } \\
\text { socially to local community }\end{array}$ & & & $\mathbf{v}$ & & 3 & $\begin{array}{l}\text { The contribution of tourism to social welfare seems to be } \\
\text { important, but still need to be improved }\end{array}$ \\
\hline Respecting local culture & $\mathbf{v}$ & & & & 1 & $\begin{array}{l}\text { The tourism managament should be paid a lot of attention } \\
\text { to local culture }\end{array}$ \\
\hline Total & & & & & 31 & \\
\hline
\end{tabular}




\section{Strengh, weakness, opportunities and threats}

Identifing destination sthrenghs, opportunities, weaknesess, threats were important in tourism stratgy development. SWOT technique provides excelent tools to describe the internal and external aspect of tourism destinations and therefore contributes significantly in drawing planning and strategic management. In case of Ijen crater, the destination strengths, opportunities, weaknesess and threats were given in Table 6 and 7.

In order to map the recent position of Ijen crater based on the SWOT analysis, the $x$ and $y$ coordinate was evaluated as follows:

$$
\begin{aligned}
\mathrm{x} & =\text { Strengths }+ \text { Weaknesses } \\
& =2.64+(-1.65) \\
& =0.99 \\
\mathrm{y} & =\text { Opportunities }+ \text { threats } \\
& =2.97+(-2.64) \\
& =0.33
\end{aligned}
$$

Based on the IFAS and EFAS matrix evvaluation, the possition of tourism in Ijen crater was located at first quadrat $(X=0.99 ; Y=$ $0.33)$. These means that tourism in ljen crater has great strenghts and opportunities for further development. The ecotourism priciples, however, should be incorporated ino future development. The position of ljen crater in quadrat first offer opportunites for further development. The proper strategy for further tourism development in ljen crater should be "Rapid Growth Strategy". This is relevan with the recent tourist arrival data to ljen crater, especially international tourist.In such strategy, however, the management authority of ljen crater should be improved several aspect related to the facility.

The natural conservation aspect become important in the tourism development in ljen. Nature as the main attraction in ljen craters should be protected from numerous potential factors of disturbance, especialy anthropogenic aspect which are related to tourist activities. Tourism from numerous countries come to ljen to observe active volcanous. Beyond ljen crater, however, there are numerous potential tourism attraction which are potential to be involved in tourism program. The contribution of stakeholder need to be improved.There are also increasing

\begin{tabular}{|c|c|c|c|c|}
\hline Factors & Internal factors & Weight & Rating & Score \\
\hline \multicolumn{5}{|l|}{ Strengths } \\
\hline Physical & $\begin{array}{l}\text { ljen crater has numerous flora-fauna which are protected by govermnetal law and } \\
\text { numerous nature-based tourism attraction }\end{array}$ & 0.33 & 3 & 0.99 \\
\hline Economy & $\begin{array}{l}\text { Support of numerous economical instrument and abundance resources to drive new } \\
\text { economic opportunities }\end{array}$ & 0.33 & 2 & 0.66 \\
\hline Social & Support of community surrounding ljen crater area & 0.33 & 3 & 0.99 \\
\hline \multicolumn{4}{|c|}{ Total strengths } & 2.64 \\
\hline \multicolumn{5}{|l|}{ Weakness } \\
\hline Physical & Limited transportation, facility and infrastructure & 0.33 & 1 & 0.33 \\
\hline Economy & Number of economic activity was limited & 0.33 & 2 & 0.66 \\
\hline Social & $\begin{array}{l}\text { Poor of government and stakeholder support to enhance community development } \\
\text { program }\end{array}$ & 0.33 & 2 & 0.66 \\
\hline \multicolumn{3}{|c|}{ Total weaknesses } & & 1.65 \\
\hline Factors & External factors & \multicolumn{2}{|c|}{ Table 7. External Strategic Factors Analysis Matriks for tourism development in ljen craters } & Score \\
\hline \multicolumn{5}{|c|}{ Opportunity } \\
\hline Phisical & $\begin{array}{l}\text { Increasing demand of qualified infrstructure and good quality of nature-based } \\
\text { tourism attraction }\end{array}$ & 0.33 & 2 & 0.66 \\
\hline Economy & Increase of tourist arrivals in ljen crater & 0.33 & 4 & 1.32 \\
\hline Social & Cultural and social capital of local community to support tourism development in ljen & 0.33 & 3 & 0.99 \\
\hline \multicolumn{4}{|c|}{ Total opportunities } & 2.97 \\
\hline \multicolumn{5}{|l|}{ Threats } \\
\hline Phisical & Increasing number of tourism contributes to environmental degradation & 0.33 & 4 & 1.32 \\
\hline Economy & $\begin{array}{l}\text { The fluctuation of tourism, increasing number of tourism providers and seller } \\
\text { contributes to the high competition and decrease of service quality }\end{array}$ & 0.33 & 2 & 0.66 \\
\hline Social & $\begin{array}{l}\text { Poor of community participation, there are another interested aspect to be } \\
\text { developed besides tourism sectors }\end{array}$ & 0.33 & 2 & 0.66 \\
\hline \multicolumn{4}{|c|}{ Total threats } & 2.64 \\
\hline
\end{tabular}
issues in community involvement and development. There are three important aspect to support tourism development, namely market promotion, infrastructure and management [13].

Table 6. Internal Strategic Factors Analysis Matriks for tourism development in ijen craters 
Principally, government plays an important role to build and maintain infrastructure. This is similar with case of Ijen craters. As a protected area, however, the establishment of infrastructure need to consider environmental aspect. In such a case government should be able to coordinate and make communication with protected forest authority to drawn the proper scenarios of infrastructure development [3].

In ljen crater, several important aspect of tourism in area with high biodiversity and cultural value need to incorporated several issues bellow:

1. Enhance the regulation to decrease and minimize illegal logging, human disturbance to conservation area, illegal hunting, and illegal collection of biodiversity from protected area.

2. Increase effort to countermeasure forest fire, especially control tourism potential to triger forest fire;

3. Increasing management strategy of conservation program;

4. Protenting key species and increasing capaicty of biodiversity conservation;

5. Increasing tourism revenue, number of labour and local community revenue from tourism bisniss;

6. Incresing organization management capacity of Protection Management Office and incresing coordination among conservation body and agency to enhance the optimal and efficnet conservation planning, programs and implemenattaion.

\section{CONCLUSION}

The proper management and ecotourism principles application in ljen Crater need to be implemented to enhance the sustainability and competitiveness ljen crater as sustainable and competitive tourism destination. Improving tourism facility and infrastructure was important aspect. The ecotourism principles is important as a key to increase tourist interest to visit ljen crater. The development and improvement of tourism facility and infrastructure, however, should be incorporates ecotourism principles. The conservation, local people and community development is crucial aspect. Involvement of stakeholder and local community in facility and infrastructure will increase the quality and sustainability of infrastructure and tourism facility.

\section{Acknowledgements}

Thanks goes to Prof. Dr. Abdul Hakim., Dr. Bagyo Yanuwiadi, Dr. Ir. Aminudin Afandhi, MS and all of the staff in Graduate program in University of Brawijaya.

\section{REFERENCES}

[1] Sharpley, R. 1994. Tourism, tourist and society. ELM Publication. Cambridgeshire.

[2] Wearing, S. and J. Neil. 1999. Ecotourism: impacts, potentials and possibilities. First Edition. Butterworth-Heinemann. Oxford.

[3] Hakim, L. 2004. Dasar-dasar pariwisata. Bayumedia. Malang.

[4] Mowforth, M. and I. Munt. 2003. Tourism and sustainability: development and new tourism in the third world. Second Edition. Routledge Taylor and Francis Group. London and New York.

[5] Office of Tourism and Culture. 2014. Ijen Crater tourism. Banyuwangi Regency.

[6] Nature Conservation Agency of East Java. 2014. Ijen Crater area management. BKSDA of East Java.

[7] Hapsari, L., A. Basith, and H. R. Novitasiah. 2014. Inventory of invasive plant species along the corridor of Kawah Ijen Nature Tourism Park, Banyuwangi, East Java. Journal of Indonesian Tourism and Development Studies 2(1), 1-9.

[8] Anonymous. 2014. Ijen Crater tourism area. www.imgbucket.com.

[9] Nazir, M. 2003. Metode penelitian. Ghalia Indonesia. Jakarta.

[10] Vanhove, N. 2011. The economics of tourism destinations. Routledge.

[11] Baud-Bovi, M., and F. Lowson. 2002. Tourism and recreation: handbook of planning and design. Architectural Press. Oxford.

[12] Bolnick, S. 2003. Promoting the culture sector through job creation and small enterprise development in SADC countries: the ethno-tourism industry. SEED Working Paper No 50. Infocus Programme on Boosting Employment through Small Enterprise Development Job Creation and Enterprise Department. International Labour Organization. Geneva.

[13] Tahajuddin, E. S. M. 2011. Pengembangan Obyek Wisata Wonderia di Kota Semarang. Thesis. Faculty of Economy, Diponegoro University. Semarang. 